\title{
PENGARUH LOCUS OF CONTROL INTERNAL DAN INTERAKSI SOSIAL TERHADAP HASIL BELAJAR MATEMATIKA
}

\author{
Dian Islamiati ${ }^{1)}$ \\ Haeruddin $^{2)}$ \\ Sugeng ${ }^{3)}$ \\ 1), 2), 3)Program Studi Pendidikan Matematika, FKIP, Universitas Mulawarman \\ Email: ${ }^{1)}$ dianislamiati1108@gmail.com
}

\begin{abstract}
ABSTRAK
Penelitian ex post facto ini bertujuan untuk mengetahui pengaruh locus of control internal dan interaksi sosial terhadap hasil belajar matematika siswa kelas VII SMP Negeri 9 Samarinda. Populasi dalam penelitian ini ialah seluruh siswa kelas VII yang berjumlah 256 siswa di SMP Negeri 9 Samarinda. Pengambilan sampel menggunakan teknik cluster random sampling, sehingga diperoleh sampel 157 siswa. Instrumen penelitian menggunakan angket dan tes hasil belajar matematika, dan sebelum digunakan untuk pengambilan data, dilakukan uji coba pada siswa kelas VII di SMP Negeri 9 Samarinda sebanyak 59 siswa. Data penelitian dianalisis menggunakan teknik statistik deskriptif dan inferensial. Hasil analisis menunjukkan bahwa locus of control internal dan interaksi sosial siswa tergolong tinggi, sedangkan untuk hasil belajar siswa tergolong pada kategori sedang. Hasil analisis inferensial, diperoleh persamaan regresi dugaan, yaitu $\hat{Y}=34,702+0,310 X_{1}+0,234 X_{2}$ dengan nilai probabilitas $\rho=0,000$. Untuk $\alpha=5 \%$, ternyata $\rho<\alpha$ sehingga persamaan regresi yang diperoleh berarti dengan $R^{2}$ sebesar 0,235 . Untuk variabel locus of control internal $\left(X_{1}\right)$ diperoleh nilai probabilitas $\rho=0,003$ dan untuk variabel interaksi sosial $\left(X_{2}\right)$ diperoleh nilai probabilitas $\rho=0,017$, sehingga terdapat pengaruh interaksi sosial terhadap hasil belajar matematika. Dengan demikian, dapat disimpulkan bahwa terdapat pengaruh locus of control internal dan interaksi sosial terhadap hasil belajar matematika siswa kelas VII SMP Negeri 9 Samarinda.
\end{abstract}

Kata kunci: Locus of Control Internal, Interaksi Sosial, Hasil Belajar Matematika

\begin{abstract}
This ex post facto study aims to determine the effect of internal locus of control and social interaction on the mathematics learning outcomes of seventh grade students of SMP Negeri 9 Samarinda. The population in this study were all students of grade VII, totaling 256 students at SMP Negeri 9 Samarinda. Sampling using cluster random sampling technique, in order to obtain a sample of 157 students. The research instrument used a questionnaire and a mathematics learning outcome test, and before it was used for data collection, a total of 59 students were tested on grade VII students at SMP Negeri 9 Samarinda. The research data were analyzed using descriptive and inferential statistical techniques. The results of the analysis showed that the internal locus of control and student social interaction were high, while the student learning outcomes were in the moderate category. The results of inferential analysis, obtained a predictive regression equation, namely $\hat{Y}=34,702+0,310 X_{1}+0,234 X_{2}$ with the probability value


$\rho=0,000$. For $\alpha=5 \%$, it turns out that $\rho<\alpha$, so that the regression equation obtained means $R^{2}$ of 0.235 . For the internal locus of control variable $\left(X_{l}\right)$ the probability value $\rho=0,003$ and for the social interaction variable $\left(X_{2}\right)$ the probability value $\rho=0,017$ was obtained, so that there was an effect of social interaction on mathematics learning outcomes. Thus, it can be concluded that there is an effect of internal locus of control and social interaction on the mathematics learning outcomes of grade VII students of SMP Negeri 9 Samarinda.

Keywords: Internal Locus of Control, Social Interaction, Mathematics Learning Outcomes

\section{PENDAHULUAN}

Berdasarkan hasil wawancara dengan guru bidang studi matematika di SMP Negeri 9 Samarinda, diketahui bahwa hasil belajar matematika siswa kelas VII masih tergolong rendah. Hal ini dapat dilihat dari nilai rata-rata ulangan harian matematika siswa yang belum mencapai standar Kriteria Ketuntasan Minimal (KKM). Siswa beranggapan bahwa usaha belajar yang dilakukan akan percuma sehingga disiplin belajar masih kurang seperti belajar dengan sungguhsungguh, bermalas-malasan di sekolah dan mengerjakan soal dengan cara menebak bahkan mencontek. Masih terdapat beberapa siswa yang kurang memiliki keyakinan terhadap kemampuan yang dimiliki dan menggantungkan hasil pencapaiannya kepada orang lain seperti mencontek pada saat diberikan tugas atau meminjam catatan milik temannya yang dianggap lebih mudah dipelajari daripada catatannya sendiri ataupun menghitung kancing baju untuk mendapatkan jawaban pada saat ulangan. Hal ini menunjukan kurangnya locus of control internal siswa terhadap hal-hal yang seharusnya diusahakan dan menjadi tanggung jawab siswa tersebut seperti belajar dengan baik agar mendapatkan nilai yang bagus dan tidak bergantung pada orang lain.

Adapun factor lain yang berpengaruh terhadap hasil belajar matematika siswa adalah interaksi sosial. Berdasarkan hasil wawancara dengan guru matematika di SMP Negeri 9 Samarinda, siswa cenderung memiliki nilai hasil belajar yang tergolong rendah diduga akibat dari rendahnya kemampuan interaksi sosial yang dialami siswa. Hal ini ditunjukan dari perilaku peserta didik seperti membentuk suatu kelompok-kelompok kecil sesuai dengan kemauan siswa tersebut. Siswa selalu memilih untuk duduk dengan teman kelompok sendiri, serta kebanyakan siswa hanya bersedia belajar bersama kelompoknya saja. Hal tersebut menjadikan hubungan antar siswa menjadi kurang harmonis sehingga menciptakan suatu interaksi sosial yang buruk antar siswa didalam kelas tersebut. Interaksi sosial siswa yang buruk membuat suasana kelas menjadi kurang kondusif dan mengakibatkan proses belajar tidak berjalan dengan baik sehingga mempengaruhi hasil belajar siswa.

Locus of control terbagi menjadi dua jenis, yaitu locus of control internal dan locus of control eksternal (Ghufron \& Rini, 2010). (Gitosudarmo \& Nyoman, 
2000) mengemukakan bahwa locus of control internal adalah kepribadian seseorang yang percaya bahwa apa yang terjadi pada dirinya terjadi atas kendalinya. Individu yang memiliki locus of control internal cenderung mengaitkan keberhasilan yang diraihnya sebagai hasil dari kerja keras dan pengetahuannya. Para ahli berpendapat bahwa individu internal lebih baik prestasinya. Individu internal lebih aktif mencari informasi sebelum mengambil keputusan, lebih termotivasi untuk mencapai hasil dan lebih berusaha untuk mengontrol lingkungannya (Muchlas, 2012).

Interaksi sosial merupakan hubungan sosial yang dinamis, yang menyangkut hubungan timbal balik antar individu, antar kelompok manusia, maupun antara orang dengan kelompok manusia (Herimanto, 2008). Sependapat dengan (Herimanto, 2008), (Syarbaini \& Rusdiyanta, 2009) juga berpendapat bahwa interaksi sosial merupakan hubungan-hubungan sosial yang dinamis yang menyangkut hubungan antara orang-orang/perorangan, dengan kelompok manusia. (Ahmadi, 2002) juga mengungkapkan pendapatnya mengenai interaksi sosial. Menurutnya, interaksi sosial adalah pengaruh timbal balik antara individu dengan golongan untuk memecahkan persoalan yang dihadapinya agar mencapai tujuan. Berdasarkan pemaparan yang telah dikemukakan, disimpulkan bahwa interaksi sosial adalah hubungan timbal balik antara dua orang atau lebih, individu yang satu mempengaruhi atau mengubah individu yang lain dan sebaliknya.
Hamalik (2001) mengemukakan bahwa hasil belajar merupakan perubahan tingkah laku pada diri siswa, yang dapat diamati dan diukur dalam bentuk perubahan pengetahuan sikap dan keterampilan. Perubahan tersebut dapat diartikan terjadinya peningkatan dan pengembangan yang lebih baik dibandingkan dengan sebelumnya, misalnya dari tidak tahu menjadi tahu, sikap kurang sopan menjadi sopan, dan sebagainya. Menurut Liebeck ada dua macam hasil belajar matematika yang harus dikuasai oleh siswa, yaitu perhitungan matematis dan penalaran matematis (Aunurrahman, 2012). Setiap proses belajar mengajar termasuk mata pelajaran matematika, keberhasilannya diukur dari seberapa jauh hasil belajar matematika yang dicapai oleh siswa disamping diukur dari segi prosesnya. Semakin baik proses pembelajaran matematika dan keaktifan siswa dalam mengikuti proses pembelajaran matematika, semakin tinggi juga hasil belajar yang diperoleh siswa. Berdasarkan pendapat yang telah dikemukakan, disimpulkan bahwa hasil belajar matematika adalah kemampuan yang telah dicapai oleh siswa setelah mengikuti pembelajaran matematika yang meliputi perhitungan matematis dan penalaran matematis yang diukur menggunakan tes.

\section{METODE PENELITIAN}

Jenis penelitian yang digunakan dalam penelitian ini adalah penelitian kuantitatif dengan menggunakan metode ex post facto. Penelitian ini melibatkan 3 variabel yaitu locus of control internal, interaksi sosial dan hasil belajar 
matematika. Untuk melihat pengaruh antara variabel-variabel bebas terhadap variabel terikat pada penelitian ini dibuat rancangan penelitian yang ditunjukkan pada gambar 1 .

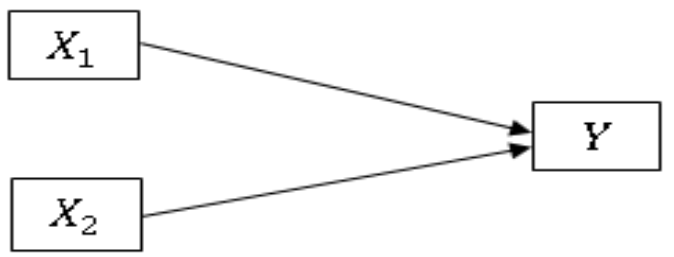

Gambar 1. Model Rancangan Penelitian

Penelitian ini dilaksanakan pada bulan F ebruari tahun ajaran 2019/2020 di SMP Negeri 9 Samarinda. Populasi dalam penelitian ini adalah seluruh siswa kelas VII SMP Negeri 9 Samarinda tahun ajaran 2019/2020 yang terdiri dari 8 kelas. Penelitian berikut menggunakan teknik probability sampling dengan metode cluster random sampling. Adapun jumlah sampel minimal yang digunakan pada penelitian ini yaitu 157 siswa.

Instrumen yang digunakan pada penelitian ini adalah angket locus of control internal dan interaksi sosial, serta tes hasil belajar matematika siswa. Untuk teknik analisis data pada penelitian ini menggunakan statistika deskriptif dan statistika inferensial, pada statistika inferensial terdapat uji asumsi dan uji hipotesis yang pada penelitian ini menggunakan regresi linier ganda menggunakan program SPSS 23.

\section{HASIL PENELITIAN DAN PEMBA- HASAN}

Berdasarkan hasil penelitian yang telah dilakukan, diperoleh data statistik deskriptif tentang locus of control internal $\left(X_{1}\right)$ seperti terlihat pada tabel 1. Dari tabel tersebut dapat disimpulkan bahwa distribusi frekuensi responden terbesar terletak pada kategori tinggi dan berdasarkan rata-rata nilai dapat dikatakan bahwa kondisi locus of control internal siswa kelas VII di SMP Negeri 9 Samarinda tergolong tinggi.

Untuk data statistika deskriptif interaksi sosial $\left(X_{2}\right)$ dapat dilihat pada tabel 2. Dari tabel tersebut dapat disimpulkan bahwa distribusi frekuensi responden terbesar terletak pada kategori tinggi dan berdasarkan rata-rata nilai dapat dikatakan bahwa kondisi interaksi sosial siswa kelas VII di SMP Negeri 9 Samarinda tergolong tinggi.

Sedangkan data statistika deskriptif hasil belajar matematika $(Y)$ dapat dilihat pada tabel 3. Dari tabel tersebut dapat disimpulkan bahwa distribusi frekuensi responden terbesar terletak pada kategori sedang dan berdasarkan rata-rata nilai dapat dikatakan bahwa kondisi hasil belajar matematika siswa kelas VII di SMP Negeri 9 Samarinda tahun ajaran 2019/2020 tergolong ke dalam kategori sedang.

Analisis inferensial yang digunakan pada penelitian ini adalah regresi linear ganda. Regresi digunakan untuk mencari pengaruh antara locus of control internal (X1) dan interaksi sosial (X2) terhadap hasil belajar matematika (Y) pada materi perbandingan siswa kelas VII SMP Negeri 9 Samarinda. Sebelum dilakukan uji hipotesis penelitian terlebih dahulu dilakukan uji asumsi. Adapun hasil uji

22 Pengaruh Locus of Control Internal dan Interaksi Sosial terhadap Hasil Belajar Matematika Dian Islamiati - Haeruddin - Sugeng 
Tabel 1. Deskripsi Data dan Distribusi Frekuensi Nilai Locus of Control Internal

\begin{tabular}{|c|c|c|c|}
\hline \multicolumn{4}{|c|}{ Deskripsi Data } \\
\hline Nilai Minimum & Nilai Maksimum & Rata-rata & Standar Deviasi \\
\hline 23 & 87 & 56,6624 & 12,25768 \\
\hline \multicolumn{4}{|c|}{ Distribusi Frekuensi Skor } \\
\hline Nilai Locus of Control Internal & $\begin{array}{c}\text { Frekuensi } \\
\text { (f) }\end{array}$ & Presentase (\%) \\
\cline { 1 - 2 } Interval & Kategori & 31 & 19,7 \\
\hline$X \leq 47$ & Sangat Rendah & 18 & 11,5 \\
\hline $47<X \leq 51$ & Rendah & 71 & 45,2 \\
\hline $51<X \leq 63$ & Tinggi & 37 & 23,6 \\
\hline $66<X$ & Sangat Tinggi & 157 & 100 \\
\hline \multicolumn{4}{|c|}{ Jumlah } \\
\hline
\end{tabular}

Tabel 2. Deskripsi Data dan Distribusi Frekuensi Nilai Interaksi Sosial

\begin{tabular}{|c|c|c|c|}
\hline \multicolumn{4}{|c|}{ Deskripsi Data } \\
\hline Nilai Minimum & $\begin{array}{c}\text { Nilai } \\
\text { Maksimum }\end{array}$ & Rata-rata & Standar Deviasi \\
\hline 23 & 90 & 57,8662 & 12,60245 \\
\hline \multicolumn{4}{|c|}{ Distribusi Frekuensi Skor } \\
\hline \multicolumn{2}{|c|}{ Interaksi Teman Sebaya } & \multirow{2}{*}{ Frekuensi (f) } & \multirow{2}{*}{ Presentase $(\%)$} \\
\hline Interval & Kategori & & \\
\hline$X \leq 39$ & Sangat Rendah & 7 & 4,5 \\
\hline $39<X \leq 52$ & Rendah & 46 & 29,3 \\
\hline $52<X \leq 64$ & Tinggi & 91 & 58,0 \\
\hline $77<X$ & Sangat Tinggi & 13 & 8,3 \\
\hline \multicolumn{2}{|c|}{ Jumlah } & 157 & 100 \\
\hline
\end{tabular}

Tabel 3. Deskripsi Data dan Distribusi Frekuensi Nilai Hasil Belajar Matematika

\begin{tabular}{|c|c|c|c|}
\hline \multicolumn{4}{|c|}{ Deskripsi Data } \\
\hline $\begin{array}{c}\text { Nilai } \\
\text { Minimum }\end{array}$ & Nilai Maksimum & Rata-rata & Standar Deviasi \\
\hline 32 & 98 & 65,8280 & 12,89016 \\
\hline \multicolumn{4}{|c|}{ Distribusi Frekuensi Skor } \\
\hline \multicolumn{2}{|c|}{ Hasil Belajar Matematika } & \multirow{2}{*}{ Frekuensi (f) } & \multirow{2}{*}{ Presentase $(\%)$} \\
\hline Interval & Kategori & & \\
\hline$X \leq 47$ & Sangat Rendah & 8 & 5,1 \\
\hline $47<X \leq 60$ & Rendah & 44 & 28,0 \\
\hline $60<X \leq 73$ & Sedang & 59 & 37,6 \\
\hline $73<X \leq 86$ & Tinggi & 34 & 21,7 \\
\hline $86<X$ & Sangat Tinggi & 12 & 7,6 \\
\hline \multicolumn{2}{|c|}{ Jumlah } & 157 & 100 \\
\hline
\end{tabular}


asumsi penelitian yang dilakukan sebagai berikut:

1. Uji Normalitas

Tabel 4. Hasil Analisis Uji Normalitas

\begin{tabular}{|l|l|}
\hline Variabel & Signifikansi \\
\hline Locus of Control Internal & 0,473 \\
\hline Interaksi Sosial & 0,730 \\
\hline Hasil Belajar Matematika & 0,955 \\
\hline
\end{tabular}

Berdasarkan hasil analisis data, diperoleh hasil uji normalitas data menggunakan uji Kolmogorov-Smirnov satu sampel yang dapat dilihat pada tabel 4. Berdasarkan tabel tersebut diperoleh taraf signifikansi statistik ( sig) $>\alpha$ yaitu 0,$473 ; 0,730 ; 0,955>$ 0,05, maka $H_{0}$ diterima sehingga dapat disimpulkan bahwa data untuk variabel locus of control internal, interaksi sosial dan hasil belajar matematika berasal dari populasi yang berdistribusi normal.

2. Uji Heteroskedastisitas

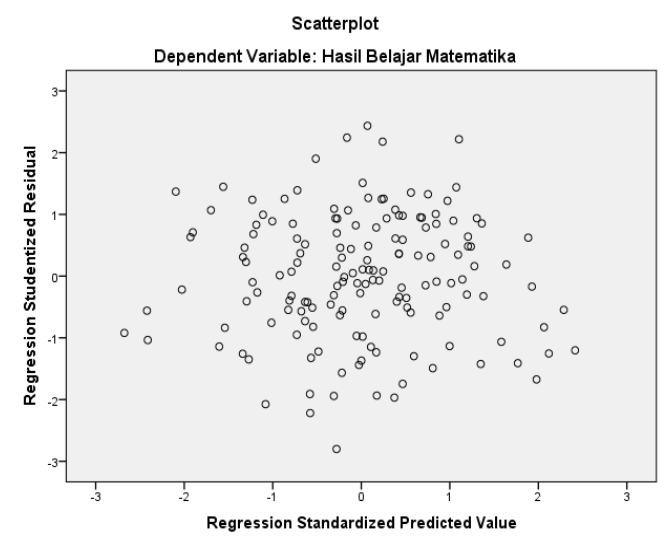

Gambar 2. Scatter Plot Dependent Variabel
Hasil uji homogenitas data dengan menggunakan program SPSS 23 dilihat dari Scatter Plot Dependent Variabel atau untuk lebih jelasnya dapat dilihat pada gambar 2. Berdasarkan hasil plot residual terhadap variabel terikat, terlihat tidak tampak adanya suatu pola tertentu pada sebaran tersebut. Oleh karena itu, dapat diasumsikan data hasil belajar matematika berasal dari populasi dengan varian homogen.

3. Uji Multikolinearitas

Tabel 5. Analisis Uji Multikolinearitas

\begin{tabular}{|c|c|c|}
\hline \multirow{2}{*}{ Model } & \multicolumn{2}{|c|}{ Collinearity Statistik } \\
\cline { 2 - 3 } & Tolerance & VIF \\
\hline $\begin{array}{c}\text { Locus of Control } \\
\text { Internal }\end{array}$ & 0,530 & 1,888 \\
\hline Interaksi Sosial & 0,530 & 1,888 \\
\hline
\end{tabular}

Perhitungan hasil analisis uji multikolinearitas dapat dilihat pada tabel 5. Berdasarkan hasil analisis dengan menggunakan program SPSS 23 diperoleh nilai VIF sebesar 1,888 yang berarti $1,888<10$ dan nilai Tolerance sebesar 0,530 yang berarti $0,530>0,1$, maka kedua variabel bebas tidak terjadi multikolinearitas.

4. Uji Autokolerasi

Perhitungan dengan menggunakan program SPSS 23 dapat dilihat pada tabel 6. Berdasarkan tabel, diperoleh Durbin-Watson sebesar 1,845 . Pembanding menggunakan nilai signify-

Tabel 6. Hasil Analisis Uji Autokorelasi

\begin{tabular}{|l|c|r|r|r|c|}
\hline \multicolumn{6}{|c|}{ Model Summary $^{\mathbf{b}}$} \\
\hline Model & $\mathrm{R}$ & $\begin{array}{c}\mathrm{R} \\
\text { Square }\end{array}$ & $\begin{array}{c}\text { Adjusted R } \\
\text { Square }\end{array}$ & $\begin{array}{c}\text { Std. Error of } \\
\text { the Estimate }\end{array}$ & $\begin{array}{c}\text { Durbin- } \\
\text { Watson }\end{array}$ \\
\hline 1 & $.485^{\mathrm{a}}$ & .235 & .225 & 11.34641 & 1.845 \\
\hline
\end{tabular}


kan 5\%, jumlah sampel 157 (n), dan jumlah variabel $3(\mathrm{k}=2)$, maka di tabel Durbin-Watson akan didapat nilai DU sebesar 1,7649. Karena nilai DurbinWatson 1,845 lebih besar dari batas atas (DU) 1,7649 dan kurang dari 4-1,7649 atau 2,2351 maka dapat disimpulkan bahwa tidak terdapat autokorelasi.

Tabel 7. Hasil Analisis Regresi Linier Ganda

\begin{tabular}{|c|c|c|c|}
\hline Variabel & $\begin{array}{c}\text { Koefisien } \\
\text { Regresi }\end{array}$ & thitung & Sig. \\
\hline Konstanta & 34,702 & 7,518 & 0,000 \\
\hline $\boldsymbol{X}_{\mathbf{1}}$ & 0,310 & 3,042 & 0,003 \\
\hline $\boldsymbol{X}_{\mathbf{2}}$ & 0,234 & 2,405 & 0,017 \\
\hline \multicolumn{2}{|c|}{$\boldsymbol{R}$} & 0,485 \\
\hline \multicolumn{2}{|c|}{$\boldsymbol{R}^{\mathbf{2}}$} & \multicolumn{2}{c|}{0,235} \\
\hline $\boldsymbol{F}_{\text {hitung }}$ & 23,669 \\
\hline
\end{tabular}

Berdasarkan hasil analisis regresi linier ganda pada tabel 7 , diperoleh nilai konstanta $\left(b_{0}\right)$ sebesar 34,702; koefisien variabel $X_{1}\left(b_{1}\right)$ sebesar 0,310; dan koefisien variabel $X_{2}\left(b_{2}\right)$ sebesar 0,234. Nilai-nilai yang diperoleh dapat disusun model persamaan regresi dugaan pada penelitian ini, yaitu:

$$
\hat{Y}=34,702+0,310 X_{1}+0,234 X_{2}
$$

Uji hipotesis selanjutnya ditentukan keberartian persamaan regresi linear dugaan. Berdasarkan hasil analisis dengan menggunakan program SPSS 23 yang terdapat pada tabel 7 , diperoleh taraf signifikan 0,000 dan $F_{\text {hitung }}=$ 23,669. Karena taraf signifikan statistik $<$ taraf signifikan pengujian, yaitu 0,000 $<0,050$ dan nilai $F_{\text {hitung }}>F_{\text {tabel yaitu }}$ 23,669 > 3,050 maka $H_{0}$ ditolak. Artinya model regresi dugaan yang diperoleh adalah berarti atau dapat dikatakan bahwa locus of control internal dan interaksi sosial berpengaruh terhadap hasil belajar matematika.
Berdasarkan hasil analisis dengan menggunakan program SPSS 23 yang dilihat pada tabel 7, diperoleh koefisien determinasi sebesar 0,235 yang berarti bahwa $23,5 \%$ hasil belajar matematika siswa dipengaruhi oleh Locus of Control Internal dan Interaksi Sosial. Sisanya ( $100 \%-23,5 \%=76,5 \%) \quad$ hasil belajar matematika dipengaruhi oleh faktor lainnya yang tidak diungkapkan dalam penelitian ini.

Uji keberartian koefisien regresi dilakukan untuk mengetahui makna dari pengaruh masing-masing variabel bebas yaitu Locus of Control Internal dan Interaksi Sosial terhadap variabel terikat yaitu Hasil Belajar Matematika, maka perlu diuji keberartian masing-masing koefisien regresi.

1. Pengaruh Locus of Control Internal terhadap Hasil Belajar Matematika

Berdasarkan hasil analisis dengan program SPSS 23 yang dapat dilihat pada tabel 7, diperoleh nilai signifikansi statistik untuk koefisien Locus of Control Internal sebesar $0,003, t_{\text {hitung }}=$ 3,042 dan $t_{\text {tabel }}=1,976$. Karena $\operatorname{sig}<\alpha$ yaitu $0,003<0,050$ dan nilai $t_{\text {hitung }}>t_{\text {tabel }}$ yaitu 3,042>1,976 maka $\mathrm{H}_{0}$ ditolak. Hal ini menunjukkan bahwa Locus of Control Internal memiliki pengaruh terhadap hasil belajar matematika setelah memperhitungkan variabel Locus of Control Internal didalam model.

Kemudian untuk koefisien regresi Locus of Control Internal diperoleh sebesar 0,310 yang menyatakan bahwa setiap peningkatan Locus of Control Internal sebesar 1 satuan maka akan meningkatkan hasil belajar matematika 
sebesar 0,310 satuan dengan skor Interaksi Sosial adalah tetap.

2.Pengaruh Interaksi Sosial terhadap Hasil Belajar Matematika

Berdasarkan hasil analisis dengan hasil analisis dengan program SPSS 23 yang dapat dilihat pada tabel 7, diperoleh nilai signifikansi statistik untuk koefisien Interaksi Sosial sebesar $0,017, t_{\text {hitung }}=2,405$, dan $t_{\text {tabel }}=1,976$. Karena sig $<\alpha$ yaitu $0,017<0,050$ dan nilai $t_{\text {hitung }}>t_{\text {tabel }}$ yaitu $2,405>1,976$ maka $\mathrm{H}_{0}$ ditolak. Hal ini menunjukkan bahwa Interaksi Sosial memiliki pengaruh terhadap hasil belajar matematika setelah memperhitungkan variabel Interaksi Sosial didalam model.

Kemudian koefisien regresi Interaksi Sosial diperoleh sebesar 0,234 yang menyatakan bahwa setiap peningkatan Interaksi Sosial sebesar 1 satuan maka akan meningkatkan hasil belajar matematika sebesar 0,234 satuan dengan skor Locus of Control Internal adalah tetap.

\section{KESIMPULAN}

Berdasarkan hasil penelitian dan pembahasan, maka kesimpulan yang dapat diambil adalah terdapat pengaruh locus of control internal dan interaksi sosial terhadap hasil belajar matematika Siswa kelas VII SMP Negeri 9 Samarinda tahun ajaran 2019/2020.

\section{DAFTAR PUSTAKA}

Ahmadi, A. (2002). Psikologi Sosial. Jakarta: PT. Rineka Cipta.

Aunurrahman. (2012). Belajar dan Pembelajaran. Bandung: Alfabeta.

Ghufron, M. N., \& Rini, R. (2010). Teori-Teori Psikologi. Yogyakarta:
Ar-Ruzz Media.

Gitosudarmo, I., \& Nyoman, S. (2000). Perilaku Keorganisasian. Yogyakarta: BPFE-Yogyakarta.

Hamalik, O. (2001). Proses Belajar Mengajar. Jakarta: Djambatan.

Herimanto, W. (2008). Ilmu Sosial dan Budaya Dasar. Jakarta: Bumi Aksara.

Muchlas, M. (2012). Perilaku Organisasi. Yogyakarta: Gadjah Mada University Press.

Syarbaini, S., \& Rusdiyanta. (2009). Dasar-Dasar Sosiologi. Yogyakarta: Graha Ilmu. 